\title{
Effect of methonolic extract of Vitex negundo on haloperidol induced catalepsy in albino mice
}

\author{
Sandeep Kumar Kamlekar*, Sangita Gupta
}

Department of Pharmacology, Geetanjali Medical College and Hospital, Udaipur, Rajasthan, India

Received: 24 January 2020

Revised: 24 February 2020

Accepted: 27 February 2020

\section{*Correspondence:}

Dr. Sandeep Kumar Kamlekar,

Email: sandeep.k.kamlekar@gmail.com

Copyright: ( $)$ the author(s), publisher and licensee Medip Academy. This is an open-access article distributed under the terms of the Creative Commons Attribution Non-Commercial License, which permits unrestricted non-commercial use, distribution, and reproduction in any medium, provided the original work is properly cited.

\section{ABSTRACT}

Background: Plants are being used in traditional medicine since history of mankind. The knowledge of these medicinal plants has accrued in the course of many centuries leading to medicinal systems in India such as Ayurveda, Unani and Siddha. Objective: In the present study, we evaluated the anticataleptic efficacy of Vitex negundo, a polyherbal formulation in haloperidol induced catalepsy in mice.

Methods: Five groups $(n=6)$ of male albino mice were used in the study. Catalepsy was induced by i.p. administration of haloperidol $(1 \mathrm{mg} / \mathrm{kg})$. The degree of catalepsy (cataleptic score) was measured as the time the animal maintained an imposed posture. We compared the anticataleptic efficacy of Vitex negundo (50, 100, 200 $\mathrm{mg} / \mathrm{kg}$ ) with standard received Pheniramine maleate $10 \mathrm{mg} / \mathrm{kg}$, i.p.

Results: In vehicle treated animals, haloperidol $(1 \mathrm{mg} / \mathrm{kg}$. i.p. $)$ produced the maximum catalepsy at $180 \mathrm{~min}$ $(46.78 \pm 3.78 \mathrm{~min})$. Standard treated as Pheniramine maleate $10 \mathrm{mg} / \mathrm{kg}$, i.p. shows maximum at $120 \mathrm{~min} .19 .24 \pm 1.32$. Test herb, i.p. Methanolic extract of Vitex negundo $(50,100,200 \mathrm{mg} / \mathrm{kg}$, i.p.) significantly potentiated haloperidol induced catalepsy at each time interval, in a dose dependent manner. At dose 50, 100 and $200 \mathrm{mg} / \mathrm{kg}$, extract of Vitex negundo (Linn.) roots showed maximum cataleptic score $12.34 \pm 0.78,14.43 \pm 0.43$ and $15.43 \pm 0.67$ min, respectively at 120 minutes in haloperidol treated animals.

Conclusions: The present study indicates that the methanolic extract of Vitex negundo reduces haloperidol-induced catalepsy in mice.

Keywords: Catalepsy, Haloperidol, Mice, Vitex negundo

\section{INTRODUCTION}

Catalepsy (tonic immobility, immobility reflex and animal hypnosis) is characterized by muscular rigidity leading to prolonged immobility and an inability to correct an externally imposed awkward posture. ${ }^{1}$ Under physiological conditions, catalepsy can be obtained in some vertebrates as a kind of passive defensive behaviour against a predator. ${ }^{2}$ In humans, excessive catalepsy-like dyskinesia is a pathological symptom occurring in schizophrenia, mood disorders (e.g. depression) and Parkinson's' disease. Catalepsy is a sign of extrapyramidal effect of drugs that inhibit dopaminergic transmission or increase histamine release in brain. ${ }^{3}$

In rodents, catalepsy can be induced by administration of the antipsychotic drug haloperidol, and such animals can be used as an appropriate model for analysis of extrapyramidal dysfunctions. Haloperidol which is used in the treatment of schizophrenia and other psychotic disorders. Antipsychotics are often associated with distressing extrapyramidal side effects. ${ }^{4}$ Haloperidolinduced catalepsy occurs due to the blockade of dopamine (D2) receptors in the substantia nigra and 
reduced dopaminergic transmission. ${ }^{5}$ Enhanced stimulation of the intrinsic central cholinergic system has also been implicated in haloperidol-induced catalepsy as it has been reported to be intensified and antagonized by pilocarpine and atropine, respectively. ${ }^{6}$ Evidence also suggests that the central serotonergic system modulates nigrostriatal dopaminergic transmission with 5$\mathrm{HT}_{3}$ antagonists reported to alleviate neuroleptic-induced catalepsy. ${ }^{7}$ The phenomenon of cataleptic immobility induced in rodents by typical neuroleptics (e.g. haloperidol) is a robust behavioural model to study nigrostriatal function and its modulation by cholinergic, serotonergic, nitrergic and other neurotransmitter systems. ${ }^{8}$

Vitex negundo (L.) (Family: Verbenaceae) commonly known as monks' pepper or five leaved chest trees (Hindi- sambhalu, nirgundi). The principal constituents the leaf juice are casticin, isoorientin, chrysophenol D, luteolin, $\mathrm{p}$-hydroxybenzoic acid and D-fructose and other constituents like vitamin $\mathrm{C}$, carotene, $\beta$-sitosterol and $\mathrm{C}$ glycoside. ${ }^{9}$ The main constituents of the oil are sabinene, linalool, terpinen-4, $\beta$-caryophyllene, $\alpha$-guaiene and globulol constituting $61.8 \%$ of the oil. The seeds contain hydrocarbons, $\beta$-sitosterol, benzoic acid and phthalic acid. ${ }^{10}$ The Vitex negundo extracts have been used in Unani system of medicine as anti-inflammatory, expectorant, tranquilizer, antispasmodic, anti convalesant, rejuvenative, antiarthritic, anthelminthic, anti-fungal and antipyretic. The Ayurvedic and Unani Pharmacopoeia of India has documented the use of the leaf, seed and the root to treat excessive vaginal discharge, edema, skin diseases, pruritus, helminthiasis. ${ }^{11,12}$

The aim of the present study was to identify the anticatalepsy activity of chosen herb in selected animal models. The objective of the study was to rule out the efficacy of the test compound with standard anti cataleptic drugs used Pheniramine malate i.p., available in market.

\section{METHODS}

\section{Animals}

Healthy adult mice weighing about 20-25gm were used for study. They were housed in polypropylene cages maintained under standard condition. The experimental protocol was subjected to the scrutiny of the Institutional Animal Ethical Committee and was cleared by the same before starting.

\section{Drugs and chemicals}

The following drugs and chemicals were used.

Drugs: Haloperidol and Pheniramine maleate purchased from commercial source. Chemicals: petroleum ether $\left(60-80^{\circ} \mathrm{C}\right)$, and tween $80 \mathrm{AR}$.

\section{Preparation of the extract}

Vitex negundo (L.) plant was identified and authenticated with a botanist. Its stem bark was separated and make in course powder after shade dried, for getting thick semisolid paste by subjecting it to maceration in $80 \%$ Methanol. The obtained semisolid thick paste was stored in refrigerator.

\section{Inclusion criteria}

Preferably small, disease free animals were selected.

\section{Exclusion criteria}

The animals not responding to the study and diseased animals excluded.

\section{Methodology}

\section{Haloperidol induced catalepsy}

Haloperidol ( $1 \mathrm{mg} / \mathrm{kg}$, i.p.) was injected to mice $(\mathrm{n}=6)$ pre-treated $30 \mathrm{~min}$ before with vehicle $(5 \mathrm{ml} / \mathrm{kg}$, i.p. $)$, and prepared extract also administered.

\section{Experimental method}

Assessment of Catalepsy was measured by the bar test. Mice were positioned so that their hindquarters were on the bench and their forelimbs rested on a $1-\mathrm{cm}$ diameter horizontal bar that was $4 \mathrm{~cm}$ above the bench. Mice were judged to be cataleptic if they maintained this position for $30 \mathrm{~s}$ or more. The length of time for which the mouse maintained this position was recorded with a stopwatch with a maximum duration of 180 seconds. The durations of catalepsy were measured at $0,30,60,90,120,150$, and 180 min. $^{13}$

\section{Collection of plant, dose selection and acute toxicity study}

Vitex negundo plant were collected from the local area in Udaipur and were authenticated by botanist. According to Borse et al, $50 \mathrm{mg}, 100 \mathrm{mg}$ and $200 \mathrm{mg}$ were selected. In the acute toxicity test, extract of Vitex negundo (Linn) plant did not produce any detectable toxicity on oral and i.p. administration. No mortality was found, which is reflected by high LD50 of extract of Vitex negundo (Linn). ${ }^{14}$

\section{Experimental design}

Mice were divided in 5 groups of 6 in each $(n=30)$, Group-I (control) served as control and received Haloperidol $1 \mathrm{mg} / \mathrm{kg}$ i.p., Group-II (standard) served as standard and received Pheniramine maleate $10 \mathrm{mg} / \mathrm{kg}$, i.p., Group-III was treated with methanol extract of Vitex negundo $(50 \mathrm{mg} / \mathrm{kg}$ ) and Haloperidol $1 \mathrm{mg} / \mathrm{kg}$ i.p., Group-IV was treated with combination of Methanol 
extract of Vitex negundo $(100 \mathrm{mg} / \mathrm{kg})$ and haloperidol 1 $\mathrm{mg} / \mathrm{kg}$ i.p. and Group-V was treatment of methanol extract of Vitex negundo $(200 \mathrm{mg} / \mathrm{kg})$ and haloperidol 1 $\mathrm{mg} / \mathrm{kg}$ i.p.

\section{Ethical clearance}

The following experimental procedures on animals was done after getting ethical clearance from IAEC Reference No. GMCH/IAEC/2019/7677(1) of Geetanjali University, Udaipur, Rajasthan.

\section{Statistical analysis}

The results were expressed as the mean \pm standard error of mean (SEM) and analysed by using one-way analysis of variance (ANOVA), followed by Dunnett's Post hoc test. A $p<0.05$ was considered statistically significant.

\section{RESULTS}

In vehicle treated animals, haloperidol ( $1 \mathrm{mg} / \mathrm{kg}$. i.p. $)$ produced the maximum catalepsy at $180 \mathrm{~min}(46.78 \pm 3.78$ min). Standard treated as Pheniramine maleate $10 \mathrm{mg} / \mathrm{kg}$, i.p. shows maximum at $120 \mathrm{~min}$. 19.24 \pm 1.32 . Test herb, i.p. Methanolic extract of Vitex negundo (50, 100, 200 $\mathrm{mg} / \mathrm{kg}$, i.p.) significantly potentiated haloperidol induced catalepsy at each time interval, in a dose dependent manner.

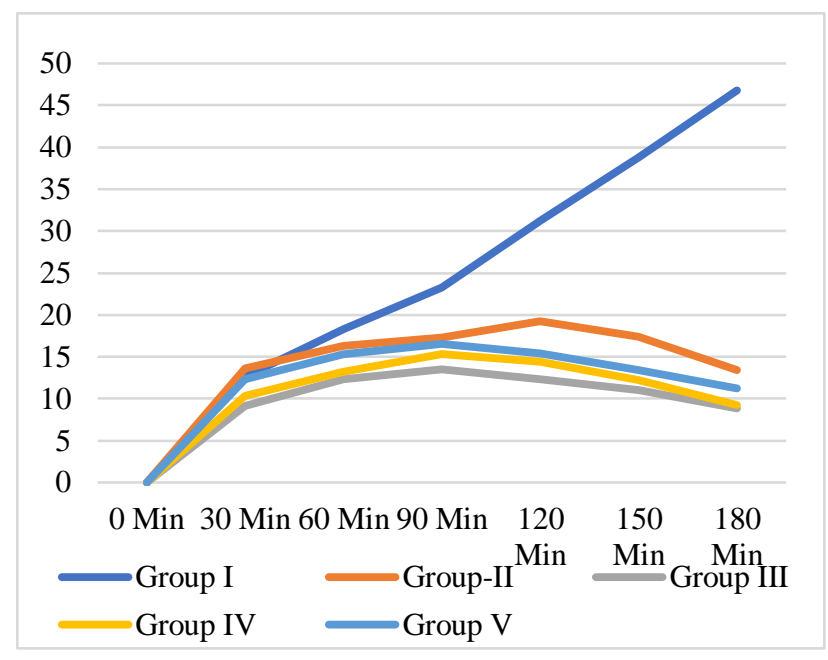

Figure 1: Effect of methanolic extract of Vitex negundo on haloperidol-induced catalepsy in mice $(n=6)$.

At dose 50,100 and $200 \mathrm{mg} / \mathrm{kg}$, extract of Vitex negundo (Linn) roots showed maximum cataleptic score $12.34 \pm 0.78,14.43 \pm 0.43$ and $15.43 \pm 0.67 \mathrm{~min}$, respectively at 120 minutes in haloperidol treated animals.

\section{DISCUSSION}

Neuroleptic-induced catalepsy in rodents has long been used as an animal model for screening drugs for Parkinsonism and it is a robust behavioural method for studying nigrostriatal function and its modulation by cholinergic, GABAergic, serotonergic and nitrergic systems. ${ }^{15-21}$ Evidence indicates that drugs which potentiate or attenuate neuroleptic induced catalepsy in rodents might aggravate or reduce the extrapyramidal side effects respectively. ${ }^{22}$

Haloperidol-induced catalepsy: Haloperidol, typical neuroleptic produces catalepsy in rodents and extrapyramidal side effects in human. ${ }^{23}$ Haloperidolinduced catalepsy is one of the animal models for testing the extrapyramidal side effects of antipsychotic drugs. ${ }^{21}$ Haloperidol, (a non-selective D2 dopamine antagonist) and metoclopramide (a potent dopaminergic blocking agent) induced catalepsy is primarily due to blockade of dopamine receptors in the striatum. ${ }^{24}$

In vehicle treated animals, haloperidol $(1 \mathrm{mg} / \mathrm{kg}$. i.p. $)$ produced the maximum catalepsy at $180 \mathrm{~min}(46.78 \pm 3.78$ min). Standard treated as Pheniramine maleate $10 \mathrm{mg} / \mathrm{kg}$ shows maximum at $120 \mathrm{~min}$. 19.24 \pm 1.32 . Test herb, i.p. Methanolic extract of Vitex negundo $(50,100,200 \mathrm{mg} / \mathrm{kg}$, i.p.) significantly potentiated haloperidol induced catalepsy at each time interval, in a dose dependent manner. At dose 50, 100 and $200 \mathrm{mg} / \mathrm{kg}$, extract of Vitex negundo (Linn.) roots showed maximum cataleptic score $12.34 \pm 0.78,14.43 \pm 0.43$ and $15.43 \pm 0.67 \mathrm{~min}$, respectively at 120 minutes in haloperidol treated animals. The agents increasing dopamine transmission inhibits neurolepticinduced catalepsy. The striatum and nucleus accumbens have been implicated as the major brain structures involved in antipsychotic induced catalepsy, which appears due to the blockade of dopamine neurotransmission. ${ }^{25}$

In present study, extract of Vitex negundo (Linn) roots (50, 100 and $200 \mathrm{mg} / \mathrm{kg}$, i.p.) significantly potentiated dose dependent haloperidol-induced catalepsy. Thus, the results suggest that extract of Vitex negundo (Linn) roots shows antidopaminergic activity.

Present study showed that the decreases in haloperidol induced catalepsy by the polyherbal formulation Vitex negundo, was comparable to the standard drug scopolamine. Moreover, the test drug had a quicker onset of action as compared to scopolamine. Vitex negundo is a polyherbal preparation containing the extracts of Withania somnifera, Ocimum sanctum, Camellia sinensis. The mechanism of anticataleptic activity of the test compound shows antidopaminerigc activity are primarily responsible for its anticataleptic activity.

\section{CONCLUSION}

In conclusion, Vitex negundo was found to be effective in reducing cataleptic scores in mice model of haloperidol induced catalepsy. Present study suggests that the test drug can be used as an alternative agent in preventing the haloperidol/neuroleptics induced extrapyramidal symp- 
toms in schizophrenic patients. However, it requires further preclinical and clinical studies to prove it.

Funding: No funding sources

Conflict of interest: None declared

Ethical approval: The study was approved by the Institutional Ethics Committee

\section{REFERENCES}

1. Herrington TM, Cheng JJ, Eskandar EN. Mechanisms of deep brain stimulation. J Neurophysiol. 2016;155:19-38.

2. Gale JT, Amirnovin R, Williams ZM, Flaherty AW, Eskandar EN. From symphony to cacophony: Pathophysiology of the human basal ganglia in Parkinson disease. Neurosci Biobehav Rev. 2008;32:378-87.

3. Anderson VC, Burchiel KJ, Hogarth P, Favre J, Hammerstad JP. Palldidal vs subthalamic nucleus deep brain stimulation in Parkinson disease. Arch Neurol. 2005;62:554-60.

4. Olanow CW, Stern MB, Sethi K. The scientific and clinical basis for the treatment of Parkinson disease. Neurology. 2009;72(4): S1-136.

5. Casseday JH, Covey EA. Neuroethological theory of the operation of the inferior colliculus. Brain Behav Evol. 1996;47:311-36.

6. Faye-Lund H, Osen KK. Anatomy of the inferior colliculus in rat. Anat Embryol. 1985;171:1-20.

7. Moore JK. The human auditory brain stem: a comparative view. Heart Res. 1987;29:1-32.

8. Satake S, Yamada K, Melo LL, Barbosa Silva R. Effects of microinjections of apomorphine and haloperidol into the inferior colliculus on prepulse inhibition of the acoustic startle reflex in rat. Neurosci Lett. 2012;509:60-3.

9. Sivarajan VV, Balachandran I. Ayurvedic drugs and their plant sources. 1st edn. Oxford and IBH publishing Co. Pvt. Ltd: New Delhi, India; 1986:329331.

10. Bhattacharjee SK. Handbook of Medicinal Plants. 1st edn. Pointer Publication, Jaipur, India; 1998:376377.

11. Bano U, Jabeen A, Ahmed A, Siddiqui MA. Therapeutic uses of Vitex Nigundo. World J Pharma Res. 2015; 4(12):589-606.

12. Tandon VR, Gupta RK. An experimental evaluation of anticonvulsant activity of Vitex-negundo. Indian $\mathbf{J}$ Physiol Pharmacol. 2005;49(2):199.

13. Sanberg PR, Pevsner J, Coyle JT. Parametric influences on catalepsy. Psychopharmacol. 1984;82:406-8.
14. Borse LB, Kottai A, Muthu A, Thangatripathi, Borse SL. Antidopaminergic Activity of Vitex negundo (Linn) plant. Asian J Chem. 2012;24(7):3171-3.

15. Khan M, Shah AJ, Gilani AH. Antidiarrheal and antispasmodic activities of Vitex negundo are mediated through calcium channel blockade. Bangladesh J Pharmacol. 2013;8:317-22.

16. Kokate CK. Practical Pharmacognosy. 4 [sup] th ed. New Delhi: Vallabh Prakashan; 1994: 104-111.

17. Evans WC. Trease and evans pharmacology. Harcourt Brace and Company. Asia. Pvt. Ltd. Singapore; 1997: 343-571.

18. Medeiros P, Viana MB, Barbosa-Silva RC, Tonelli LC, Melo-Thomas L. Glutamatergic neurotransmission in the inferior colliculus influences intrastriatal haloperidol-induced catalepsy. Behav Brain Res. 2014;268:8-13.

19. Melo LL, Santos P, Medeiros P, Mello RO, Ferrari EA, Brandão ML, et al. Glutamatergic neurotransmission mediated by NMDA receptors in the inferior colliculus can modulate haloperidolinduced catalepsy. Brain Res. 2010;1349:41-7.

20. Sanberg PR, Bunsey MD, Giordano M, Norman AB. The catalepsy test: its ups and downs. Behav Neurosci. 1988;102:748-59.

21. Melo LL, Brandão ML. Role of 5-HT1A and 5-HT2 receptors in the aversion induced by electrical stimulation of inferior colliculus. Pharmacol Biochem Behav. 1995;51:317-21.

22. Van OJ, Kapur S. Schizophrenia. Lancet. 2009;374:635-45.

23. Miyamoto S, Duncan GE, Marx CE, Lieberman JA. Treatments for schizophrenia: a critical review of pharmacology and mechanisms of action of antipsychotic drugs. Mol Psychiatr. 2005;10:79-104.

24. Pratt J, Winchester C, Dawson N, Morris B. Advancing schizophrenia drug discovery: optimizing rodent models to bridge the translational Nat Rev Drug Discov. 2012;11:560-79.

25. Kapur S, Mamo D. Half a century of antipsychotics and still a central role for dopamine D2 receptors. Prog Neuropsychopharmacol Biol Psychiatr. 2003;27:1081-90.

Cite this article as: Kamlekar SK, Gupta S. Effect of methonolic extract of Vitex negundo on haloperidol induced catalepsy in albino mice. Int $\mathbf{J}$ Basic Clin Pharmacol 2020;9:621-4. 